\title{
A history of tobacco production and marketing in Malawi, 1890-2010
}

Prowse, Martin Philip

Published in:

Journal of Eastern African Studies

DOI:

10.1080/17531055.2013.805077

Publication date:

2013

Document version

Peer reviewed version

Citation for published version (APA):

Prowse, M. P. (2013). A history of tobacco production and marketing in Malawi, 1890-2010. Journal of Eastern African Studies, 7(4), 691-712. https://doi.org/10.1080/17531055.2013.805077 
This article was downloaded by: [Copenhagen University Library], [Martin Prowse] On: 19 J une 2013, At: 00:22

Publisher: Routledge

Informa Ltd Registered in England and Wales Registered Number: 1072954 Registered

office: Mortimer House, 37-41 Mortimer Street, London W1T 3J H, UK

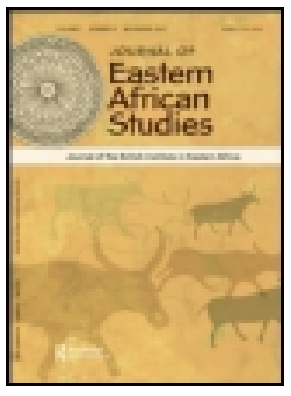

\title{
J ournal of Eastern African Studies
}

Publication details, including instructions for authors and subscription information:

http:// www. tandfonline.com/loi/ rjea20

\section{A history of tobacco production and marketing in Malawi, 1890-2010}

\author{
Martin Prowse ${ }^{a b}$ \\ a Department of Geosciences and Natural Resource Management, \\ University of Copenhagen, Copenhagen, Denmark \\ ${ }^{b}$ Institute of Development Policy and Management (IOB), \\ University of Antwerp, Lange St. Annastraat 7, B-2000 , \\ Antwerp, Belgium \\ Published online: 18 J un 2013.
}

To cite this article: Martin Prowse (2013): A history of tobacco production and marketing in Malawi, 1890-2010, J ournal of Eastern African Studies, DOI: 10.1080/ 17531055. 2013.805077

To link to this article: http:// dx.doi.org/ 10.1080/ 17531055.2013.805077

\section{PLEASE SCROLL DOWN FOR ARTICLE}

Full terms and conditions of use: http://www.tandfonline.com/page/terms-andconditions

This article may be used for research, teaching, and private study purposes. Any substantial or systematic reproduction, redistribution, reselling, loan, sub-licensing, systematic supply, or distribution in any form to anyone is expressly forbidden.

The publisher does not give any warranty express or implied or make any representation that the contents will be complete or accurate or up to date. The accuracy of any instructions, formulae, and drug doses should be independently verified with primary sources. The publisher shall not be liable for any loss, actions, claims, proceedings, demand, or costs or damages whatsoever or howsoever caused arising directly or indirectly in connection with or arising out of the use of this material. 


\title{
A history of tobacco production and marketing in Malawi, 1890-2010
}

\author{
Martin Prowse ${ }^{\mathrm{a}, \mathrm{b} *}$ \\ ${ }^{a}$ Department of Geosciences and Natural Resource Management, University of Copenhagen, \\ Copenhagen, Denmark; ${ }^{b}$ Institute of Development Policy and Management (IOB), University of \\ Antwerp, Lange St. Annastraat 7, B-2000, Antwerp, Belgium
}

(Received 21 June 2012; final version received 21 March 2013)

\begin{abstract}
During the past century tobacco production and marketing in Nyasaland/Malawi has undergone periods of dynamism similar to changes since the early 1990s. This article highlights three recurrent patterns. First, estate owners have fostered or constrained peasant/smallholder production dependent on complementarities or competition with estates. Second, the rapid expansion of peasant/smallholder production has led to large multiplier effects in tobacco-rich districts. Third, such expansion has also led to re-regulation of the marketing of peasant/smallholder tobacco by the (colonial) state. The article concludes by assessing whether recent changes in the industry - such as district markets, contract farming with smallholders, and the importance of credence factors - have historical precedents, or are new developments in the industry.
\end{abstract}

Keywords: Malawi; tobacco; peasants/smallholders; history

\section{Introduction}

Since 1990 smallholders have grown an increasing proportion of Malawi's main export crop - burley tobacco - growing up to $60 \%$ of total production. Through synthesising key historical and contemporary sources (in particular, the work of McCracken, Ng'ong'ola and White), this article foregrounds historical precedents for the rapid increase in smallholder tobacco production since 1990. It highlights one feature of the relationship between estate and peasant/smallholder production during the last century: that estate owners have attempted to promote or limit smallholder production dependent on how this dovetailed with or threatened estate production. The article also highlights how rapid expansion of peasant/smallholder production in the 1920s, 1940s and 1990s led to large multiplier effects in tobacco-rich districts and the re-regulation of marketing of smallholder produce by the (colonial) state.

Although scholars have made tentative connections between smallholder burley production since 1990 and changes in production and marketing in prior decades, ${ }^{1}$ none has synthesised historical sources in a systematic manner. This article uses the historical record to make four arguments: first, that democratisation altered estate owners' ability to limit smallholder production when this competed with estate production through the 1990s; second, that the re-regulation of the marketing of smallholder produce in the early 2000s has clear precedents in the 1920s and 1940s; third, that peasants/smallholders maintained or even increased tobacco production

*Email: martin.prowse@geo.ku.dk 
when substantial controls were put in place, reflecting how a stable and tightly regulated marketing structure has not been inimical to peasant/smallholder success; and fourth, that while certain recent changes in the industry, such as the creation of district markets and the introduction of contract farming with smallholders by leaf merchants, have historical precedents, two recent changes appear novel: direct state involvement in processing and exporting tobacco, and the importance of credence factors such as ensuring tobacco is not produced using child labour. This article aims mainly to provide a concise historical synthesis as a reference point for scholars and students wishing to pursue further and more detailed analyses of Malawi's main industry. Future research might fruitfully focus on the two new aspects of the industry highlighted by the fourth argument.

The article has six sections. First, it shows how changing global demand for tobacco has influenced the fortunes of four different styles of production in Nyasaland/Malawi configured around contrasting labour relations and access to land. The historical analysis then covers four periods, separated for heuristic purposes: 1880-1927 - Early Colonialism up to the Great Depression; 1928-1961 - From the Depression to Independence; 1961-1989 - The Postcolonial Malawian State; and 1990-2010 - Democratisation and Liberalisation. The final section concludes with a consideration of current and future trends in Malawi's tobacco production.

\section{Global demand and styles of production in Nyasaland/Malawi}

The history of tobacco in Malawi broadly reflects shifts in global demand where changes in consumer preferences have altered the supply of tobacco types. The recent dominance of Virginia- or American-blended cigarettes has led to production of light tobaccos - such as burley and flue-cured tobacco - instead of dark leaf such as fire cured, used in pipes and snuff. ${ }^{2}$ Changes in demand and production have reconfigured curing practices and labour relations. Different types of leaf require different curing techniques, and are also influenced by the environment and agronomy. Specific types of tobacco are grown using specific labour regimes. ${ }^{3}$ For example, flue-cured tobacco has mainly been grown on estates using direct labour not annual tenants, due to high labour and capital requirements. Thus, increased flue production on estates has changed the terms on which labour is engaged. Burley and fire-cured tobaccos, on the other hand, have been grown using different labour regimes, including estate tenants, estate out-growers and peasant/smallholder production. Thus, the four main labour regimes for tobacco production in Nyasaland/Malawi can be characterised as follows: ${ }^{4}$

- Estate production with 'direct' wage labour - estate labour production.

- Estate production with tenants - estate tenant production.

- Customary land production of tobacco where seedlings are provided by, and the crop is marketed through, an estate - estate out-grower production.

- Customary land production - peasant/smallholder production.

The changes between these 'styles' of production must be understood in relation to the colonial influence on Malawi's economy. ${ }^{5}$ The colonial economy had a tripartite structure: first, a large-scale European-owned estate sector producing cotton, tea, tobacco and coffee in accordance with local conditions and global demand; second, peasant production of cash crops such as cotton, tobacco and groundnuts when conditions and constraints allowed; and third, national and regional migrant labour 
of a formal and informal nature. ${ }^{6}$ These three elements were often in conflict, leading to 'a number of distinctively different rural economies'?

Whilst migration from the 'dead' Northern Region is one example of a specific rural economy, ${ }^{8}$ tobacco also played a major role in creating distinctive regions. For example, tobacco in the Southern Region was dominated by large-scale estates thus limiting the availability of customary land. In the Central Region widespread largescale estates only emerged from the 1970s with earlier attempts superseded by successful peasant production.

Tobacco production also played a pivotal role in class formation, in terms of the national political elite in colonial and postcolonial periods, and rural elites amongst peasant/smallholder populations. As the following narrative demonstrates, colonial planters and estate owners used leverage over the administration to maintain control over crops, marketing and, in some cases, the supply of labour to estates, with distinct differences between Southern and Central Regions. In the immediate postcolonial period, tobacco production created and maintained the African political elite through the redistribution of colonial estates and alienation of customary land. For example, this class, through the Tobacco Association of Malawi (TAMA), resisted reforms around 1990 that would allow smallholders to grow burley, as this would reduce the supply of tenants onto estates. In addition, throughout the last century increases in peasant/smallholder production has always led to the formation of a rural elite, at certain times fostered by the state as 'Master' or 'Progressive' farmers.

Before we begin the journey through the last century, we also need some understanding of the crop itself. Three generic characteristics are important. First, tobacco does not benefit from economies of scale: production occurs on both smalland large-scale units, often leading to co-existence. Second, during the last two centuries 'tobacco cultivation has been characterised by a distinct dualism, between the [often] small scale of growing operations and the giant scale of manufacturing and marketing,. 9 Third, due to the nature of tobacco, its voracious demand for labour (and, possibly, as nicotine is absorbed through the skin), a 'tobacco culture' is created in societies deeply involved in production. In other words, there is a distinct culture to tobacco agriculture because each 'grower has to tend his tobacco not by fields, not even by plants, but leaf by leaf. [...] Everything to do with tobacco is hand work - its cultivation, harvesting, manufacture, sale, even its consumption'. ${ }^{10}$ We now turn to the early decades of large-scale tobacco export from the British Central African Protectorate/Nyasaland.

\section{0-1927: Early colonialism to the Great Depression}

During the 1890s two colonial planters, Hynde and Stark, initiated large-scale export of Nicotiana tabacum adjacent to what is now Zomba. ${ }^{11}$ Hynde noticed the local practice of curing a shorter and bushier local species of tobacco, Nicotiana rustica, in hut roofs, and distributed tabacum seedlings to tenants and adjacent peasants on customary land. ${ }^{12}$ This fire-cured venture was bought by a Scottish-based firm - the Blantyre and East Africa Company (BEAC) - in 1901, and estate tenant and estate out-grower production grew on and around the company's estates. ${ }^{13}$

Tobacco's significance increased in the first years of the 20th century. As coffee prices plummeted and the viability of rubber and cotton exports became uncertain, tobacco became more attractive. The BEAC turned towards flue-cured production. ${ }^{14}$ 
In 1903 the company hired two Americans from Virginia who successfully launched flue-cured production on the 3.5 million acres alienated to 400 Europeans in $1891 .{ }^{15}$

\section{Arrival of the Imperial Tobacco Company (ITC)}

Attracted by the incipient flue-cured industry, and the new railway linking Blantyre to the Shire River, the Imperial Tobacco Company (ITC) became a vital player in the industry. ${ }^{16}$ The ITC was an agglomeration of leading UK tobacco firms formed in 1902 in response to the American Tobacco Company's interest in the British tobacco market. ${ }^{17}$ The British Central Africa Protectorate offered an opportunity to diversify supplies away from the United States, so ITC built a factory close to Blantyre to process and handle tobacco for the United Kingdom. ${ }^{18}$ Operations began in 1908 with the company buying half the national crop. ${ }^{19}$ By 1913 flue-cured production was 'the largest growth of Virginian tobacco which has ever been produced outside of America'. ${ }^{20}$

The ITC's impact on the industry was substantial: it guaranteed a local market for estates, but created divisions within the settler community by favouring certain growers. ${ }^{21}$ In addition, the ITC demanded flue-cured tobacco, which was only grown by Europeans. As noted above, flue-cured tobacco is a capital- and labour-intensive crop, predominantly grown using direct labour. There were two further reasons for using this labour regime, both rooted in the colonial discourse of paternalism and racism. ${ }^{22}$ First, the ITC stated flue-cured tobacco was 'too technical for native growers'. ${ }^{23}$ The second explanation was the racialised separation of 'light' tobaccos for whites and 'dark' tobaccos, such as fire-cured, for black Africans, reflecting how race was a structuring principle in colonial economic and consumer practices. ${ }^{24}$

\section{Alomwe migrants and thangata labour}

Between 1914 and 1919, flue-cured production on estates in the Southern Region continued to increase. To support this industry, the supply of labour was encouraged through an annual hut tax of one to two months' wages. ${ }^{25}$ This proved insufficient in providing labour at the right time. ${ }^{26}$ from the planters' perspective, 'salvation came from an unexpected source in the immigration of many thousands of people from Mozambique'. ${ }^{27}$ Alomwe migrants, anxious to avoid harsh colonial policies in neighbouring Portuguese East Africa, settled on estates in the south. Migrants' residence rights were based on the provision of one month's thangata labour for estate rent, and another for the Protectorate's hut tax. ${ }^{28}$ Estate owners stretched the length of each 'month' with the recently arrived Alomwe in a powerless position. ${ }^{29}$

The arrival of a vulnerable population in need of land 'overcame the contradiction in the economy: how to pay three shillings per month when people could make $£ 2$ or $£ 3$ elsewhere in the regional economy. ${ }^{30}$ Whilst the exploitation of thangata was recognised by the colonial administration, attempts to curb worst practices were amended or delayed by the leverage of estate owners. A case in point is that of A. L. Bruce, owner of the Magomero Estate, who successfully argued the Ordinance for Compulsory Written Contracts of 1914 between employers and African residents would 'retard development and the extension of lands for plantations', ${ }^{31}$ thus delaying the implementation of this bill. ${ }^{32}$ In addition to an ample supply of cheap labour, the industry received another boost with the introduction of Imperial Preference in 1919. 
Increased demand allowed estate producers to compete better with US producers and acreage under flue increased to over 21,000 in $1921 .^{33}$

Whilst greater tobacco acreage was good news for struggling estates, it was not for tenant families engaged in thangata due to more labour demands. ${ }^{34}$ The exploitation of thangata became more apparent through comparisons with peasants earning many times tenants' annual pay from fire-cured production on customary land. ${ }^{35}$ For example, rural elites started engaging labour and Zomba District became 'overrun with European buyers prepared to pay one shilling per pound for fire-cured tobacco and offering advances to individual growers to build brick barns for curing, ${ }^{36}$ The increase in peasant production, and the scramble to market the crop, was an early indication of the rapid expansion during the 1920s.

\section{Peasant production and the Native Tobacco Board (NTB)}

The 1920s heralded the arrival of peasants as a major force in the tobacco industry. The story of how two British settlers, A. F. Barron and R. Wallace, initiated production in the Central Region has been recounted concisely by numerous scholars. ${ }^{37}$ The key point to note is that production in the Central Region (known as the Central Province) was fundamentally different from the south: only 30,000 acres were alienated to European settlers. This second phase of tobacco expansion in Nyasaland was based on estate out-grower production initially, and subsequently peasant/smallholder production on customary land.

In May 1920 Barron and Wallace obtained 2000 acres of leasehold land close to a small settlement called Lilongwe. After dabbling in flue-cured production, Barron and Wallace initiated fire-cured production after the ITC guaranteed to purchase the crop. $^{38}$ This proved successful, so in 1923 Barron started estate out-grower production by distributing seedlings to adjacent peasants. Their supply response was prolific: 25 tons in 1924, 192 tons in 1925 and 880 tons in $1926 .{ }^{39}$ This had a remarkable impact on the local economy:

Trading stores reeled under the clamour for consumer goods. Bicycles, the prized possession of teachers or Government clerks and object of desire for most Africans were now bought outright for ten pounds. One grower even bought himself a new motor car. $^{40}$

Whilst peasants were enjoying their newly found wealth, Barron and Wallace encountered two problems: transport to the ITC factory in Limbe, and purchasing the crop. Initially Barron and Wallace had a de facto monopsony over customary land production, but their success attracted traders who, without overhead costs, flocked to the Central Region eager to cash in.

They set up in opposition to the established buying centres; along roads and paths, and tucked away in the bush, thus forcing those who had done the spade work to follow them if they wished to buy an adequate proportion of the tobacco which they had so enterprisingly inspired. ${ }^{41}$

To defend their interests, Barron and Wallace requested the colonial government grant a de jure monopsony. The request was turned down on the grounds it would have been 'against everything that was British'. ${ }^{42}$ The boom in peasant production concerned the administration. They noted the lack of regulation, poor leaf quality, 
overproduction and the inflationary effect of the marketing frenzy. ${ }^{43}$ In addition, the expansion precipitated concerns about the neglect of food crops, ${ }^{44}$ and the timber used for curing. ${ }^{45}$ Such concerns partly contributed to the creation of the Native Tobacco Board (NTB) in the 1926 Tobacco Ordinance. ${ }^{46}$

However, this is only one side of the story. Although 'charged with the duties of supervising and assisting native tobacco growers', ${ }^{47} \mathrm{NTB}$ controls on customary land production were also due to planters' self-interest in curbing peasant production which was undermining estates. ${ }^{48}$ The challenge peasant production gave planters is clearly shown when one considers in 1917 estates constituted $96 \%$ of total production but by 1929 peasants produced $63 \%$ of tobacco. ${ }^{49}$ The link between estate owners' interests and the NTB's actions in constraining peasant production is supported by the composition of the NTB executive at this time: W. T. Bowie, manager of the BEAC estates, Barron, and an influential Italian estate owner - Conforzi - were all members. ${ }^{50}$

One important reason for peasants' supply response was the ability to pay the hut tax without recourse to labour migration. ${ }^{51}$ Although this did not greatly affect Central Region estate owners, who relied on estate tenant and estate out-grower production, estate owners in the Southern Region were reliant on direct labour to produce flue resented customary land production, as it reduced labour supply. ${ }^{52}$ From this perspective, customary land production would lead to 'the eventual ruination of the European planter', and estate owners in the Southern Region looked to Southern Rhodesia where massive land alienation had produced a captive proletarian labour force. $^{53}$

The success of Barron and Wallace in stimulating customary land production thus precipitated a split within the settler tobacco community: an estate-based European flue-cured community dependent on direct labour (mainly in the south), and a fire-cured community with production by peasants, out-growers or tenants but where marketing was controlled by Europeans, mainly in the centre. ${ }^{54}$ The creation of the NTB in 1926 reinforced the control of the latter over the marketing of peasant production and protected estate tenant production. ${ }^{55}$

The NTB used different methods to constrain customary land fire-cured production: the 1926 Tobacco Ordinance required all customary land growers to register with the district commissioner, and a tax was placed on all customary land tobacco levied on buyers (but passed onto producers) ${ }^{56}$ Moreover, estate owners fine-tuned legislation through the Tobacco Ordinances of 1928, 1930 and 1931. For example, the NTB closed a number of markets between 1929 and 1934, leaving only three, all concentrated around Lilongwe. ${ }^{57}$ Customary land production stagnated between 1929 and 1939, declining in areas no longer serviced by district-level markets. ${ }^{58}$ Thus, the political leverage of estate owners, along with the ineptitude of the colonial administration, stymied the most prolific style of tobacco production seen in Nyasaland. ${ }^{59}$

The early decades of tabacum production in the British Central African Protectorate/Nyasaland show the influence of the ITC, the exploitative thangata on estates in the Southern Region, and the fast expansion of peasant production of fire-cured tobacco in the Central Region. Moreover, they illustrate the connected nature of estate and peasant production - how estates promoted peasant production to a point, then constrained it. In addition, these early decades highlight how the increase of smallholder production in the 1920s contributed to two clear outcomes: a large multiplier effect in rural districts, and the re-imposition of control by the state 
over the marketing of smallholder tobacco through the creation of the NTB. We also see how total smallholder production stayed constant despite such controls.

\section{8-1961: From the depression to independence}

If the early years of the century brought the promise of prosperity for estate owners in the Southern Region, the late 1920s and 1930s brought despair. A fall in flue-cured tobacco prices in 1927 and subsequent depression meant the European industry received a shock from which it never recovered' ${ }^{60}$ These decades saw the end of European family-run settler farms in the south, ${ }^{61}$ and their aggregation into largescale company estates. ${ }^{62}$ As estates became insolvent, estate owners asked the administration for assistance citing Southern Rhodesia as a precedent. ${ }^{63}$ Whilst some loan payments were initiated, they were not sufficient, and were 'unable to prevent many white farmers from going to the wall'. ${ }^{64}$ At this time some estates were insulated from the depression by guaranteed marketing contracts with the ITC.

The decline of estates in the south was accompanied by a shift from estate labour production to estate tenant production of fire-cured production. ${ }^{65}$ For example, Figure 1 shows estate tenant production increased from $£ 1$ million pounds in 1929 to over $£ 5$ million pounds in 1939. Moreover, in the south the number of tenants on estates tripled between 1927 and 1931. ${ }^{66}$ The shift to estate tenant production also benefited estate owners: it transferred production risk onto tenants, and provided a sedentary labour force that included women and children. ${ }^{67}$

After 1928 there were substantial differences in estate tenancy in the south and centre. The Nyasaland Planters Association (NPA), representing estate owners in the Central Region, managed to restrict the 1928 Tobacco Ordinance, which had provided some protection to tenants, to units over 10,000 acres (found mainly in the south). Southern tenants were then able to straddle estate tenancy and customary land production. ${ }^{68}$ In contrast, as they were outside the scope of the 1928 Ordinance, estate owners in the Central Region could 'demand a much higher level of commitment than could be exacted from tenants in the south' ${ }^{69}$ Annual verbal agreements meant unproductive tenants were easily evicted. Despite little protection, the number of tenants in the centre still grew rapidly, from 500 in 1927 to over 7500

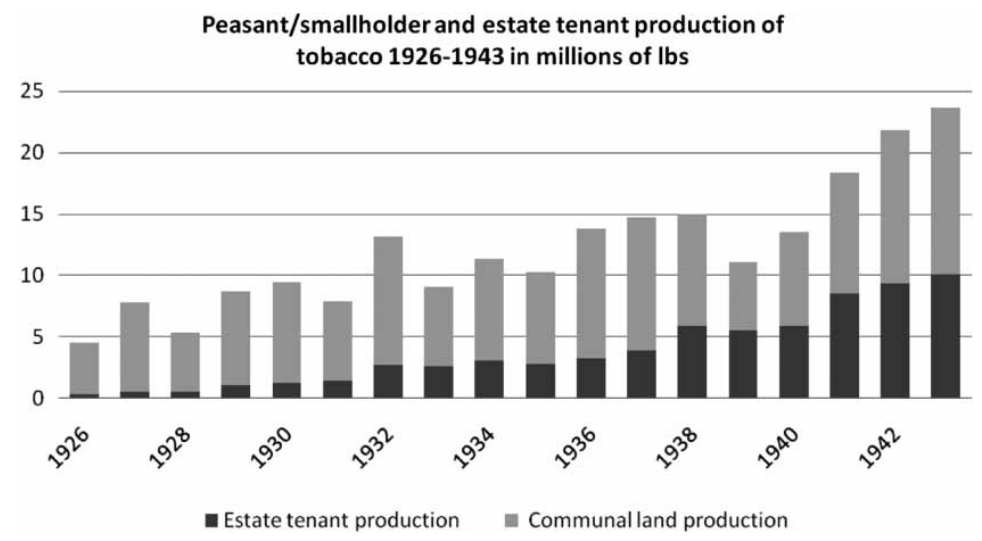

Figure 1. Estate tenant and customary land production of tobacco, 1926-1943 (£, millions). Source: Anthill, "History of the Native Grown Tobacco Industry of Nyasaland," 1945. 
in 1938, clustered around Lilongwe, with tenants coming from areas of the Central Region not serviced by the NTB, the Shire Highlands and Mozambique. ${ }^{70}$ The growth of estate tenant production in the south and centre meant owners essentially converted 'estates into concessions within which they held monopoly rights of purchase of the produce'. ${ }^{71}$ To support estate tenant production, the NTB intensified constriction of customary land production in the centre, for example by limiting the size of tobacco plots. $^{72}$ Despite policies to reduce competition with estate owners, peasants/smallholders continued to produce the majority of Nyasaland tobacco at this time.

\section{Arrival of the auction floor}

The NTB's policies led to unrest amongst peasants in the Central Region. Discontent simmered through the 1930s until very low prices in 1937 led to riots at the few remaining NTB markets. ${ }^{73}$ The NTB responded by banning traders and claiming a monopsony over customary land tobacco. By purchasing the entire crop and transporting it from NTB markets to the auction floor in Limbe, ${ }^{74}$ the NTB regulated competition between exporters, maintained quality and also generated substantial rents through the difference between producer prices and those paid by exporters at auction. ${ }^{75}$ The NTB now opened markets in the south for the first time ${ }^{76}$ curtailing the ability of traders and estates to act as a marketing channel. ${ }^{77}$

\section{The Second World War and the expansion of smallholder fire-cured production}

The Second World War had a profound influence on the industry. Greater UK demand and limited supplies from the United States boosted production. ${ }^{78}$ The NTB reversed its policy of restraint and promoted the tobacco on customary land. ${ }^{79}$ During the war the NTB did not have capacity to buy all customary land tobacco and peasants turned to estates to market crops. ${ }^{80}$ McCracken characterises the period from 1940 to 1947 as being one of 'uncontrolled expansion' with much higher prices paid to peasants. ${ }^{81}$ Figure 1 shows how customary land production increased from $£ 5$ million to over $£ 13$ million pounds between 1939 and 1943, with estate tenant production (which probably contained some peasant/smallholder production marketed through estates) doubling during this time period.

For customary land growers higher prices meant a return to the boom times: 'Trading stores, unable to cope with the demand for goods, soon exhausted their supplies leaving the African tobacco grower-consumers, with their fists full of pounds, resorting to cash bartering for goods from fellow growers. ${ }^{82}$ But just as with the smallholder boom of the 1920s, rapid customary land production led to concerns. The Acting Director of Agriculture noted a 'rapid decline in soil fertility in the heavily settled tobacco areas'. ${ }^{83}$ In addition, the Governor of Nyasaland stated 'the high prices paid to producers have had the effect of unbalancing the whole of our agricultural production. Indeed, if some remedial action is not taken, a serious shortage of food will result in a very short time'. ${ }^{84}$

The colonial administration's fears about the declining supply of food crops were realised in 1949 when Nyasaland, and the Southern Region in particular, suffered a famine. In her account, Vaughan highlights a possible hectarage trade-off between tobacco and maize as a contributory factor to the crisis. ${ }^{85}$ Vaughan also highlights the importance of gender, age and employment opportunities at the micro-level in 
explaining entitlement failure. ${ }^{86}$ The colonial government responded to the crisis by re-imposing strict controls on customary land production: the 1948 Tobacco Ordinance re-established the NTB's monopsony; some estate owners purchasing customary land tobacco were prosecuted ${ }^{87}$ tobacco prices were fixed by the NTB (with a substantial premium for quality leaf); ${ }^{88}$ and from 1950 all tobacco growers were subject to compulsory registration. ${ }^{89}$ Unsurprisingly, the numbers of customary land growers dropped: by over $50 \%$ in the south, and by over $15 \%$ in the centre. ${ }^{90}$

But despite greater regulation, tobacco exports increased by almost $50 \%$ between 1947 and 1953, ${ }^{91}$ particularly from customary land in the Central Region. Here, McCracken highlights the role of " "progressive" farmers who employed wage labour, both permanent and casual and cultivated up to 20 acres". ${ }^{92}$ In contrast, the $1950 \mathrm{~s}$ saw estates' share of tobacco exports decline. In the Central Region, estates started to focus on a new, lucrative type of leaf - burley tobacco - leaving fire-cured to smallholder growers. ${ }^{93}$ As we have seen, along with flue-cured tobacco, burley was reserved exclusively for estates. By 1960, most of the 5900 tenants in the Central Region were producing burley. ${ }^{94}$

There were also marketing changes. In 1955 the NTB merged with the cotton and maize marketing boards to create the Agricultural Production and Marketing Board, which later became the Farmers Marketing Board (FMB). This new centralised body became a focal point for nationalist criticism from Dr Kamuzu Banda, as did political union with Northern and Southern Rhodesia, and labour conditions on tobacco estates. $^{95}$

But Dr Banda's political rhetoric was not matched by action, and, through lobbying and appeals to the UK government, Central Region estate owners received a temporary exemption from a 1962 Ordinance supporting tenants' rights. ${ }^{96}$ The reprieve was extended in following years, and estate tenant production survived decolonisation later to expand from the late 1960s with the participation of the African political elite.

Significant changes took place in the tobacco industry between the depression and 1960: the collapse of flue-cured production on estates; the NTB's policy of constraining peasant production; the creation of the auction floor system; the rapid increase in customary land production in the 1940s; the emergence and reservation of burley tobacco for estates; and that labour relations on estates became a focus of nationalist criticism.

Moreover, the period from 1927 to 1960 again highlights the close relationship between estate and smallholder production, where the NTB's policy of constraining customary land production from 1927 to 1939 was to accommodate estate tenant production. We also see the uncontrolled expansion of peasant/smallholder production during the 1940s led both to a boom-time economy and the re-imposition of controls over peasant/smallholder marketing. Furthermore, we also see that despite greater controls in the early 1930s and late 1940s, peasants/smallholders managed to maintain or increase production.

\section{1-1989: The postcolonial Malawian state}

From 1961 until 1968 (with political independence in 1964) the Malawian government promoted smallholder production on customary land. ${ }^{97}$ In addition to supporting rural Malawi Congress Party (MCP) followers, the policy was aimed at 'progressive' achikumbe farmers of the $1950 \mathrm{~s},{ }^{98}$ partly via improving extension 
services and infrastructure. ${ }^{99}$ Ng'ong'ola suggests there was a sharp increase in control over agricultural production at this time, such that 'settler or African intermediaries should not be allowed to compete with the FMB in the marketing of all African food or cash crops'. ${ }^{100}$ with most government expenditure and support aimed at customary land producers, the productivity of tobacco estates in the Central Region contracted sharply.

Despite promoting smallholder production, there was no attempt at large-scale land reform at independence. For example, whilst government did purchase a limited number of estates, ${ }^{101}$ the transfer of land from Europeans to state and African Malawian ownership occurred mainly in the 1970s, when the Land Act of 1967 was also used to alienate customary land. ${ }^{102}$

The pro-peasant policies of the 1960s did elicit some growth in customary land production, but were confronted with a lack of a sustained supply response. ${ }^{103}$ Government started to look towards the estate subsector again. For example, it cancelled reforms to allow smallholder production of burley in $1965 .^{104}$ The move back towards estates was precipitated by a severe current account deficit in 1968, ${ }^{105}$ and nationalist hostility to the estate subsector, so vehement in the early 1960s, began to wane. ${ }^{106}$

Thus, in the late 1960s the Malawian political elite became heavily involved in estate tobacco production. ${ }^{107}$ Through the 1960s the FMB bought abandoned exEuropean estates, and around 1966 starting selling these assets to the MCP political elite through issuing loans and providing management services. ${ }^{108}$ The attractiveness of estate production increased as Rhodesia's Unilateral Declaration of Independence in 1965 led to the imposition of sanctions on Rhodesia in 1966, and thereby increased demand for Malawian tobaccos, and international leaf merchants - such as Universal Leaf - began to look to Malawi as a location to increase supply. ${ }^{109}$ Interest in estate tobacco production was augmented by high prices in $1968 .{ }^{110}$ These factors set the scene for the rapid expansion of estates in the 1970s.

\section{Large-scale estate expansion in the 1970s}

The 1970s saw the creation of numerous new estates and the redistribution of estate land from old European settler families to government-affiliated organisations and the political elite. Kydd splits the growth of the estate sector through the 1970s into two periods of growth prior to a 'crisis of viability'. ${ }^{111}$ The first period of growth (1969-1972) was when General Farming (owned by President Banda and the FMB), and Press Farming, as well as the MCP political elite, created estates mainly from customary land. ${ }^{112}$ President Banda was at the forefront of indigenising estate ownership, asserting that 'every Minister must have an estate. [...] I am right up to neck in debt but I will pay the debt one day'. ${ }^{113}$ Estate expansion from 1969 was also based on compulsory purchase of European-owned estates and their redistribution to the African elite, the Malawi Young Pioneers, General Farming and Press Holdings. ${ }^{114}$ Europeans in the Central Region had some licences revoked in 1970, whilst Asian tobacco farmers' licenses were cancelled in $1974 .{ }^{115}$ In many cases, Europeans were allowed to keep hold of one estate with others redistributed. ${ }^{116}$ This was the time when the structure of the postcolonial economy was set. Banda and his political allies' control of the core of the Malawian economy (Press Holdings, Malawian Development Corporation, ADMARC), as well as over the financial 
sector (National Bank of Malawi, Commercial Bank of Malawi) continued for at least two decades. ${ }^{117}$

Kydd's second period of growth (1973-1977) saw the broadening of estate ownership with further leasehold estates created from customary land mainly in the Central Region. President Banda and the MCP ensured capital for estate expansion from the Commercial Bank and Reserve Bank. ${ }^{118}$ The provision of loans, along with licence, was a key form of patronage. ${ }^{119}$ Investment in estates occurred through an intricate set of financial arrangements between state bodies, parastatals and private companies, ${ }^{120}$ with some finance for leasehold estate expansion generated from ADMARC's 'implicit taxation' of smallholders, which also cross-subsidised consumer maize prices. ${ }^{121}$ In many cases, estate tenant production was based on annual tenants from the land-constrained south.

The end of the 1970s led to a 'crisis of viability' for the estate subsector. ${ }^{122}$ In addition to the excessive lending by Malawian banks, and poor estate management, the Malawian economy suffered exogenous shocks which exposed the limitations of a dualistic agricultural development strategy. ${ }^{123}$ The complex relationships between key economic institutions (ADMARC, Malawi Development Corporation, Press Holdings) were no longer viable, leading Malawi to open negotiations with the international financial institutions. ${ }^{124}$

Structural adjustment loans in the 1980s reflected the price-ism and state minimalism prevalent at this time, ${ }^{125}$ and aimed to tackle the anti-smallholder bias of previous decades, such as the annexation of customary land and ADMARC's monopsony over cash crops, including fire-cured tobacco. ${ }^{126}$ The first three structural adjustment loans aimed to remove price distortions, such as subsidies on fertilisers, to reduce the role of ADMARC in marketing smallholder produce, and to increase production of smallholder export crops by increasing producer prices relative to food crop production, such that they were closer to export parity. One rapid consequence of this sequence of policy reforms was an expansion of fire-cured tobacco. Despite the relatively modest increase, especially when compared with the 1920s and 1940s, this expansion still managed to precipitate concerns over the supply of food crops. ${ }^{127}$

\section{Small-scale estate expansion in the 1980s}

The estate subsector also changed radically in this decade. Large-scale estate expansion of the 1970s was replaced by small-scale estate expansion driven by civil servants, previous estate managers and employees, and the conversion of customary land into leasehold land by 'graduating' smallholders. ${ }^{128}$ The number and area of estates increased rapidly and their average size declined. Estate expansion was fastest in the Central Region, ${ }^{129}$ almost entirely based on estate tenant production of burley. ${ }^{130}$ Prices paid to tenants by estate owners were set nationally by the Tobacco Association of Malawi (TAMA) but were only $19-40 \%$ of average prices received on the floors. ${ }^{131}$ In this respect, through TAMA the estate-owning class operated in a parasitic manner, utilising their privileged access to burley tobacco marketing quotas and capital to exploit poorer often land-constrained smallholders. ${ }^{132}$

In summary, despite attempting a smallholder-led growth strategy, from the late 1960s government relied on an estate-led growth path. During the 1970s and 1980s the number of estates expanded rapidly and ownership broadened to include members of the rural elite. Importantly, this period also illustrates how the MCP political elite, who were large-scale estate owners, constrained peasant/smallholder 
production through continuing to reserve burley and flue-cured tobacco for estates. Although government experimented with smallholder burley production in the early 1980s with favourable results, burley remained an estate only crop until the 1990s, as the MCP political elite replicated the paternalistic arguments used by the ITC 80 years previously: that peasants/smallholder did not have the technical ability to grow quality tobacco leaf.

\section{0-2010: Democratisation and liberalisation}

The reform of burley tobacco production and marketing in the 1990s was the first major attempt to change the colonial structure of Malawi's economy. ${ }^{133}$ It was broadly supported by two donors - The World Bank and USAID. ${ }^{134}$ Burley reform emerged after the collapse of The World Bank's third structural adjustment loan in $1987,{ }^{135}$ and the re-evaluation of structural adjustment lending in the country. ${ }^{136} \mathrm{At}$ this time donors were keenly concerned with reducing human rights abuses and ensuring a smooth transition to democracy. The World Bank's Agricultural Sector Adjustment Credit of 1990 led to smallholder burley production quotas, and facilitated smallholder access to the auction floors, measures which chimed with broader moves towards democratisation. Once restrictions had been lifted, smallholder burley production expanded rapidly: the number of smallholder clubs increased from around 500 in 1991 to 30,000 in 2000, and then declined to around 20,000 between 2001 and 2003. ${ }^{137}$ Smallholder burley production increased from 10,000 metric tons in 1994 to around 80,000 tons from 1997 to 2003. ${ }^{138}$ This rapid increase was accompanied by a decline in estate burley production.

Two main arguments explain why smallholder burley production undermined estates. $^{139}$ First, estates found it difficult to recruit tenants, as higher incomes on customary land increased rural wages, forcing up prices paid to tenants and reducing profits. Second, the marketing structure for smallholder burley was liberalised as part of USAID's Agricultural Sector Adjustment Programme of 1994, which led to the introduction of intermediate buyers. With echoes of the 1920s, van Donge highlights how these traders created an anonymous marketing channel that encouraged the theft of estate tobacco, encouraged estates and smallholders to default on loans (as these are repaid via the auction floors), and lowered the quality of tobacco brought to the auction floors, as many traders did not have a good knowledge of tobacco, thus lowering the reputation of Malawian burley on international markets. ${ }^{140}$

This period also witnessed a geographical shift in smallholder tobacco production from the south to the centre and north. For example, Prowse highlights how the Central Region's share of smallholder burley production increased from $35 \%$ to $45 \%$ from 1997 to 2003, whilst the Northern Region's increased from 27\% to 34\%. The Southern Region's share declined from $38 \%$ to $21 \% .{ }^{141}$ More specifically, smallholder burley production became most concentrated in Kasungu and Rumphi districts. ${ }^{142}$

The rapid increase in smallholder burley production from 1990 led to what are now quite familiar outcomes. First, there was an economic boom in districts where smallholder production was concentrated. For example, The World Bank claimed 'smallholder profits from burley sales have provided the largest ever cash injection of income in rural Malawi'. ${ }^{143}$ In the crop marketing season, rural towns and trading centres in tobacco districts attract growers whose incomes percolate through town and district economies, pulling in traders and seasonal migrants. ${ }^{144}$ Second, the rapid increase in smallholder burley production also led to government re-regulation of 
the marketing of the smallholder crop. In the late 1990s, intermediate buyers were seen by many stakeholders as detrimental to the industry. Government attempted to ban intermediate buyers in 2000, but donors refused to accept this. ${ }^{145}$ Intermediate buyers were finally banned in 2002-2003, and once again only producers could market tobacco on the auction floors.

Similar to the 1920s and 1940s, in the 1990s and early 2000s we see that the efforts to control the marketing of smallholder produce were driven both by the vested interests of estate owners and by a genuine concern by government and stakeholders to ensure the long-term vitality of the industry. Full liberalisation allowed intermediate buyers to undermine estates, loan repayments and the reputation of Malawian tobacco. In this respect, re-regulating the marketing of smallholder tobacco brought substantial benefits to all producers and, importantly, smallholders continued to produce similar quantities despite greater regulation.

But this is not to say the institutional structure of the industry in the early 2000s benefited smallholders to the extent it should have. It is well known the Malawian tobacco value chain is governed by the leaf merchants. In the early 2000s Limbe Leaf was the dominant merchant and was the leading actor in a cartel that depressed prices and vigorously protected their rents. This allegation is confirmed by analysis conducted by Prowse based on key informant interviews and Auction Holdings sales figures for 2004. ${ }^{146}$ Prowse statistically corroborates the allegations that the auction floor was carved up each day and that leaf companies bought bales in a predetermined buying sequence. ${ }^{147}$

Recent years have seen considerable changes in the industry: the expansion of contract farming with smallholders; the creation of district markets; conflict between government and leaf merchants; the introduction of minimum prices; and much greater attention to credence issues, such as child labour and green tobacco sickness. We now turn our attention to each of these changes, and consider if these can be considered a 'new' phenomenon.

Contract farming by leaf merchants started in 2001-2002 when Stancom financed production on Press Agriculture estates, which had stopped growing tobacco in 2000. In 2002-2003 the dominant leaf merchant Limbe Leaf signed a fiveyear deal with Press Agriculture to produce flue on 65 Press Agriculture estates. It received Presidential authority to bypass the auction and take this leaf straight to processing factories. It is claimed that leaf companies under-declared the amount of tobacco grown and smuggled leaf out of the country to avoid liabilities. Thus, from 2003-2004 government ensured all 'financed' leaf was marketed through a 'silent auction' system on the auction floors, where prices are fixed according to predetermined grades.

Contract farming was also initiated with smallholders at this time, first through Limbe Leaf's purchase of Kasungu Flue-cured Tobacco Authority (KFCTA) in 2000, and slightly later with Dimon contracting 2500 smallholders in Kasungu, Lilongwe, south Mzimba and Rumphi. By 2009, 60 million kilograms of burley ( $30 \%$ of the total crop) were produced through contract farming with all leaf merchants operating large-scale agronomic operations. ${ }^{148}$ Leaf merchants wish to move to a $100 \%$ contract farming system due to pressure from cigarette manufacturers for full traceability (see the discussion below on credence factors), but as of July 2012 this has been resisted by government. ${ }^{149}$ A complete shift to contract farming has ramifications for many associated industries: inputs suppliers, transporters and graders. In addition, arguments for $100 \%$ contract farming underestimate the role 
the auction floor plays: Auction Holdings recovers the costs of goods and services from growers' gross proceeds for firms and institutions. It is also understandable if government is reticent about closing the auction floors due to the alleged smuggling when merchants were contracting large-scale estates.

Reflecting back on the last century or more, the rapid increase of contract farming with smallholders is a modern-day equivalent of traders offering advances to customary land growers in the Southern Region in the 1910s to build brick barns for fire-cured tobacco. Moreover, current problems with side-selling within contract farming arrangements, when a smallholder sells contracted tobacco to a trader, across the border, or to another firm, are modern-day equivalents of the difficulties encountered with out-grower production by Barron and Wallace in the 1920s, or during the uncontrolled expansion of the 1940s. ${ }^{150}$

A second recent change has been the creation of district markets to reduce congestion and inefficiencies at the three auction floors in Limbe, Lilongwe and Mzuzu. These district markets are at Ngodi, Kasungu, in the Central Region, and at Chinkhoma, in the Southern Region. They have also reduced the attractiveness of the cross-border trade. ${ }^{151}$ As the above narrative amply demonstrates, district markets are not new, for example the NTB operated district markets between 1926 and 1937 before the NTB claimed a monopsony over all customary land tobacco.

A third recent feature of the industry has been a serious conflict between government and leaf merchants, which has led to the deportation of senior managers. This conflict was partly caused by merchants operating the buying cartel during the early 2000s. These concerns led government to introduce minimum prices for each grade of tobacco. It also led government, via Auction Holdings, to support the creation of a new leaf merchant called Malawi Leaf to inject greater competition at auction. TAMA also entered this node of the value chain through collaboration with Premium Tobacco Holdings. This company started constructing its own processing plant to overcome the larger firms' control of the capital goods for processing tobacco. ${ }^{152}$ Looking back at the historical overview, we can see how the practice of minimum prices partly reflects the fixed prices offered by the NTB after the 1948 Tobacco Ordinance. ${ }^{153}$ The overview does not, however, offer any obvious precursors to direct state involvement in processing and exporting of tobacco, and as such this can be seen as a new development.

The final change has been the increasing importance of credence issues, such as the prevalence of child labour or green tobacco sickness. In an industry often seen as a pariah, manufacturers are desperate to avoid bad publicity and prevent pressure from anti-tobacco lobbies. Manufacturers are demanding full traceability from suppliers on issues such as the elimination of child labour. Contract farming, where the entire production process is overseen by leaf merchant agronomists, is one way of addressing these credence concerns. The need for tobacco to adhere to such credence factors does not appear to have any historical precedents.

\section{Conclusion}

This overview presents four arguments regarding the history of tobacco in Malawi. First, democracy reduced the ability of estate owners to prevent or constrain smallholder production when it emerged as a dynamic force in the 1990s and threatened estate production. Second, the re-imposition of controls on the marketing of smallholder tobacco in the early 2000s has clear precedents in the 1920s and 1940s. 
Third, the article highlights how peasants/smallholders maintained or even increased total tobacco production when such substantial controls were imposed, showing how shifts from a laissez-faire approach to a more regulated marketing structure have not been antithetical to continued peasants/smallholders success. Fourth, the article also uses a historical narrative to assess recent changes in the industry, and argues that two changes appear novel: direct state involvement in processing and exporting tobacco; and the current importance of credence factors, such as the need for merchants to guarantee tobacco is not produced using child labour.

Broadening the discussion, it is likely Malawi will remain reliant on tobacco for the foreseeable future. In this respect, the findings highlighted by this review could suggest future trends. This is not to say, of course, that history can predict future scenarios accurately. With this caveat in mind, this overview suggests estate owners might initiate and increase out-grower activities because they can provide the requisite oversight and traceability now required. Second, institutions concerned with diversifying Malawi's agricultural production away from tobacco could do worse than focus on the smallholders' investment patterns from tobacco income. In other words, organisations could try to provide incentives so multiplier effects in tobacco districts are directed towards profitable long-term diversification. ${ }^{154}$ Finally, the expansion of contract farming with smallholders and greater governance of the value chain by leaf merchants requires greater regulation from government. For example, legislation that sets out the rights of parties inserts default clauses into contracts (especially in the case of force majeure) and outlines dispute-resolution procedures. ${ }^{155}$ Government could also ensure a fair balance between contracted tobacco and leaf sold on the auction floors to ensure a price-discovery mechanism and so that smallholders maintain a choice of marketing channels.

\section{Acknowledgements}

The author thanks numerous anonymous reviewers, the journal Editors, Colin Murray, Phil Woodhouse, Jane Harrigan, Admos Chimhowu, Pius Nyambara, Joseph Mtisi and Christopher Phiri for comments on previous versions of this article. Any inaccuracies or misinterpretations are solely the responsibility of the author.

\section{Notes}

1. Van Donge, "Disordering the Market"; Tobin and Knausenberger, "Dilemmas of Development."

2. Goodman, Tobacco in History.

3. Akehurst, Tobacco.

4. In colonial times communal land was referred to as crown land or trust land. I solely use the term 'customary land'. The terms 'smallholder' and 'peasant' are used interchangeably.

5. McCracken, "Peasants, Planters and the Colonial State: Case of Malawi."

6. Vail, "State and the Creation"; Vaughan, Story of an African Famine; McCracken, "Peasants, Planters and the Colonial State: Case of Malawi"; McCracken, "Planters, Peasants and the Colonial State: Impact of the Native Tobacco Board"; Andersson, "Informal Moves, Informal Markets."

7. McCracken, "Peasants, Planters and the Colonial State: Case of Malawi," 22.

8. Andersson, "Informal Moves, Informal Markets."

9. Goodman, Tobacco in History, 193.

10. Ortiz quoted in ibid., 166.

11. Ibid. 
12. Ibid.

13. Baker, Nyasaland, 15.

14. Ibid.

15. Rangeley, "Brief History, Part 1"; Rangeley, "Brief History, Part 2"; Krishnamurthy, "Economic Policy"; Palmer, "Johnston and Jameson."

16. Davies, Fifty Years of Progress.

17. Goodman, Tobacco in History.

18. Davies, Fifty Years of Progress.

19. Rangeley, "Brief History, Part 1"; Rangeley, "Brief History, Part 2."

20. Rangeley, "Brief History, Part 2," 76.

21. Here we can see an early form of marketing contracts used by the ITC.

22. Ng'ong'ola, "Malawi's Agricultural Economy."

23. Wilshaw, Century of Growth, 25.

24. Mintz, Sweetness and Power; Fanon, Black Skin.

25. Palmer, "Johnston and Jameson."

26. White, Magomero; Chirwa, Alomwe.

27. White, Magomero, 87.

28. Krishnamurthy, "Economic Policy."

29. White, Magomero, 89-90.

30. Vail, "State and the Creation," 51.

31. Bruce quoted in Krishnamurthy, "Economic Policy," 395.

32. White, Magomero.

33. Vail, "State and the Creation"; Vaughan, "Food Production."

34. Kandawire, "Structure of the Colonial System," 42. The thangata system was justified in the colonial discourse by claiming the practice had indigenous precedents. See also White, Magomero, 150-2.

35. White, Magomero, 153.

36. Ibid. Here we can also see an early form of contract farming, where peasants were lent credit (inputs) in exchange for exclusive purchase rights over the crop.

37. Anthill, "History of the Native Grown Tobacco Industry"; Rangeley, "Brief History, Part 1"; Rangeley, "Brief History, Part 2"; Davies, Fifty Years of Progress; McCracken, "Peasants, Planters and the Colonial State: Case of Malawi"; McCracken, "Planters, Peasants and the Colonial State: Impact of the Native Tobacco Board"; Wilshaw, Century of Growth.

38. Wilshaw, Century of Growth. Here again we see the ITC using marketing contracts.

39. McCracken, "Planters, Peasants and the Colonial State: Impact of the Native Tobacco Board."

40. Wilshaw, Century of Growth, 47.

41. Anthill, "History of the Native Grown Tobacco Industry," 56.

42. Wilshaw, Century of Growth, 47.

43. Ng'ong'ola, "Malawi's Agricultural Economy," 248.

44. Wilshaw, Century of Growth, 48.

45. McCracken, "Experts and Expertise."

46. Van Donge, "Disordering the Market." As van Donge notes, the NTB did play a role in ensuring the quality of peasant fire-cured tobacco. However, van Donge appears too generous towards the NTB in the late 1920s and 1930s, highlighting their regulatory role in protecting quality, as opposed to constraining peasant/smallholder production to allow expansion of estate tenant production.

47. Blunt, Report of a Commission, 21.

48. McCracken, "Peasants, Planters and the Colonial State: Case of Malawi"; McCracken, "Planters, Peasants and the Colonial State: Impact of the Native Tobacco Board"; Palmer, "White Farmers in Malawi"; Ng'ong'ola, "Malawi's Agricultural Economy."

49. Rangeley, "Brief History, Part 1"; Rangeley, "Brief History, Part 2."

50. McCracken, "Planters, Peasants and the Colonial State: Impact of the Native Tobacco Board," 177.

51. Vail, "State and the Creation."

52. Quotation in Vail, "State and the Creation," 62; Chanock, "Political Economy of Independent Agriculture," 125. 
53. White, Magomero, 171.

54. Rangeley, "Brief History: Part 2," 77.

55. Ng'ong'ola, "Malawi's Agricultural Economy." The timing of the closure of minimarkets appears significant as it corresponds to the switch by estates in the Central Region from estate labour production of flue-cured towards fire-cured estate tenant production, following the collapse of flue prices in 1927.

56. Ibid.

57. McCracken, "Planters, Peasants and the Colonial State: Impact of the Native Tobacco Board."

58. Ibid.; Anthill, "History of the Native Grown Tobacco Industry."

59. See the words of Kenyon-Slaney, Lilongwe District Commissioner in 1934, quoted in McCracken, "Planters, Peasants and the Colonial State: Impact of the Native Tobacco Board," 178.

60. Anthill, "History of the Native Grown Tobacco Industry," 57.

61. Palmer, "Johnston and Jameson," 214.

62. Chirwa, "Garden of Eden."

63. Power, "Race, Class, Ethnicity."

64. Palmer, "Johnston and Jameson," 240.

65. Blunt, Report of a Commission.

66. Chirwa, "Garden of Eden."

67. Chirwa, "Child and Youth Labour."

68. Chirwa, "Garden of Eden," 279-80. One reason was the NTB was not active in this region until 1938, and, unlike the Central Region, customary land producers benefited from competition between traders.

69. McCracken, "Sharecropping in Malawi," 40.

70. McCracken, "Economics and ethnicity."

71. White, Magomero, 175. See also the quotation in Palmer, "Johnston and Jameson," 237-8.

72. Vail, "State and the Creation"; McCracken, "Planters, Peasants and the Colonial State: Impact of the Native Tobacco Board." Further measures to squeeze customary land production included: Palmer, "Johnston and Jameson," extending leasehold estates from 21 to 99 years in 1931; McCracken, "Planters, Peasants and the Colonial State: Impact of the Native Tobacco Board," granting new land leases to European planters in the Central Region in 1932 (including NTB members); and Kandawire, "Structure of the Colonial System," amending the Native Authority Ordinance of 1933 so it did not apply to estate land.

73. Rangeley, "Brief History: Part 1," 40-1.

74. McCracken, "Planters, Peasants and the Colonial State: Impact of the Native Tobacco Board."

75. Kydd and Christiansen, "Structural Change in Malawi." This approach was continued for many decades by consecutive state marketing boards.

76. Rangeley, "Brief History, Part 1"; Rangeley, "Brief History, Part 2."

77. Woelk et al., "Prospects for Tobacco Control." A similar set of policies were enacted at this time in Southern Rhodesia where auction floors and the Tobacco Marketing Board were created in 1936.

78. Gately, La Diva Nicotina.

79. Ng'ong'ola, "Malawi's Agricultural Economy," 250. The 1946 Tobacco Ordinance relaxed restrictions on tobacco production and allowed onto the NTB Board some Africans. See also McCracken, "Planters, Peasants and the Colonial State: Impact of the Native Tobacco Board."

80. McCracken, "Sharecropping in Malawi." This practice, illegal under the 1926 Tobacco Ordinance, was widespread. It was legalised in the 1946 Tobacco Ordinance.

81. McCracken, "Planters, Peasants and the Colonial State: Impact of the Native Tobacco Board."

82. Wilshaw, Century of Growth, 70.

83. McCracken, "Planters, Peasants and the Colonial State: Impact of the Native Tobacco Board," 187.

84. Governor Colby quoted in ibid. 
85. Vaughan, Story of an African Famine, 78.

86. Ibid.

87. McCracken, "Planters, Peasants and the Colonial State: Impact of the Native Tobacco Board."

88. Ibid.

89. Rangeley, "Brief History, Part 1"; Rangeley, "Brief History, Part 2."

90. McCracken, "Planters, Peasants and the Colonial State: Impact of the Native Tobacco Board."

91. Vail, "State and the Creation," 72.

92. McCracken, "Planters, Peasants and the Colonial State: Impact of the Native Tobacco Board," 191.

93. Ibid.

94. McCracken, "Sharecropping in Malawi."

95. Ng'ong'ola, "Malawi's Agricultural Economy." See the words of Dr Kamuzu Banda, Minister of Agriculture, quoted in McCracken, "Sharecropping in Malawi," 55.

96. Ng'ong'ola, "Malawi's Agricultural Economy".

97. Kydd, "Malawi in the 1970s."

98. Ibid.

99. Vail, "State and the Creation."

100. Ng'ong'ola, "Malawi’s Agricultural Economy," 255.

101. Akehurst, Tobacco.

102. Sahn and Arulpragasam, Development Through Dualism?

103. Mkandawire, Poverty, Democracy and Macro Economic Management.

104. Orr, "Green Gold?" The estate sector's exclusive rights over burley and flue-cured tobacco created in the 1952 Tobacco Ordinance were reinforced by the 1962 Africans on Private Estates Ordinance, and later by the 1972 Special Crops Act.

105. Baker, Nyasaland.

106. McCracken, "Sharecropping in Malawi." This is clearly articulated in the government's 1971 DevPol planning document.

107. Ibid., 58.

108. Kydd, "Malawi in the 1970s."

109. Ibid.

110. McCracken, "Sharecropping in Malawi."

111. Kydd, "Malawi in the 1970s."

112. Ibid.

113. Quoted in Pryor, Political Economy of Poverty, 81.

114. Van Donge, "Disordering the Market."

115. Thomas, "Economic Developments in Malawi."

116. McCracken, "Sharecropping in Malawi."

117. Pryor and Chipeta, "Economic Development Through Estate Agriculture."

118. Kydd, "Malawi in the 1970s." Growth in this period was supported, in part, by the Lome convention of 1973, which gave duty free access to European Commission markets.

119. Mkandawire, Poverty, Democracy and Macro Economic Management.

120. Harrigan, From Dictatorship to Democracy, 35.

121. Kydd and Christiansen, "Structural Change in Malawi"; Harrigan, From Dictatorship to Democracy.

122. Kydd, "Malawi in the 1970s."

123. Harrigan, From Dictatorship to Democracy, 40-1.

124. Ibid.

125. Mosley and Toye, "Design of Structural Adjustment Programmes."

126. Harrigan, From Dictatorship to Democracy.

127. Ibid.

128. Conroy, "Economics of Smallholder Maize Production."

129. Sahn and Arulpragasam, Development Through Dualism?, 15.

130. Kydd and Hewitt, "Effectiveness of Structural Adjustment Lending."

131. Mkandawire, Poverty, Democracy and Macro Economic Management.

132. For example, see USAID, Agricultural Sector Assistance Program (ASAP). A further example of TAMA's exploitative practices can be seen in rents the organisation accrued 
through maintaining a monopoly over the supply of hessian sacks, a monopoly which only ended in the late 2000 s.

133. Harrigan, From Dictatorship to Democracy.

134. World Bank, Report and Recommendation; USAID, Agricultural Sector Assistance Program ( $A S A P)$.

135. Government of Malawi, Statement of Development Policies 1987-1997.

136. Harrigan, From Dictatorship to Democracy.

137. Author's estimates based on Tobacco Control Commission datasets. Each of these clubs consisted of around 12-20 smallholder farmers.

138. Jaffee, Malawi's Tobacco Sector; Prowse, "Becoming a Bwana."

139. World Bank, Accelerating Malawi's Growth; Jaffee, Malawi Agriculture; Van Donge, "Disordering the Market."

140. Van Donge, "Disordering the Market."

141. Prowse, "Becoming a Bwana," 579.

142. Prowse, "Burley Tobacco"; Benson et al., Malawi - An Atlas of Social Statistics.

143. World Bank, Accelerating Malawi's Growth, iv. Numerous studies highlight the large multiplier effect in rural economies at this time, e.g. Zeller, Growth Linkages; Evans, Rapid Assessment; Orr, "Green Gold?"; and Peters, "Rural Income and Poverty."

144. Prowse, "Becoming a Bwana."

145. Van Donge, "Disordering the Market."

146. Prowse, Comparative Value Chain Analysis.

147. Ibid.

148. Contract farming is a contentious issue within academic and policy debates. For recent overviews, see Oya, "Contract Farming"; and Prowse, Contract Farming in Developing Countries.

149. For a full discussion, see Moyer-Lee and Prowse, How Traceability.

150. It is not clear if processors/exporters contacted growers in the early decades of the century. We have seen how the ITC provided marketing contracts to favoured estates, but it is not clear if this involved the provision of inputs.

151. For a full discussion of the cross-border trade, see Prowse, Comparative Value Chain Analysis.

152. For a full discussion, see Prowse, Comparative Value Chain Analysis; and Moyer-Lee and Prowse, How Traceability.

153. There is a difference here between the NTB fixing prices when enjoying a monopsony and government trying to enforce minimum prices at auction.

154. Prowse, "Becoming a Bwana."

155. Prowse, Contract Farming in Developing Countries.

\section{References}

Akehurst, B. C. Tobacco. London: Longman, Green \& Co., 1968.

Andersson, J. A. "Informal Moves, Informal Markets: International Migrants and Traders from Mzimba District, Malawi." African Affairs 105, no. 420 (2005): 375-397.

Anthill, R. M. "A History of the Native Grown Tobacco Industry of Nyasaland." Nyasaland Agricultural Quarterly Journal 5, no. 5 (1945): 49-65.

Baker, C. A. "Nyasaland, the History of its Export Trade." Nyasaland Journal 15, no. 1 (1962): $7-35$.

Benson, T., J. Kaphuka, and S. Kanyanda. Malawi - An Atlas of Social Statistics. Washington, DC: National Statistical Office, Government of Malawi, and International Food Policy Research Institute, 2002.

Blunt, D. L. Report of a Commission Appointed to Enquire into the Tobacco Industry of Nyasaland. Zomba: Nyasaland Protectorate Government, 1939.

Chanock, M. "The Political Economy of Independent Agriculture in Colonial Malawi: The Great War to the Great Depression.” Journal of Social Science 1 (1972): 118-128.

Chirwa, W. C. "Alomwe and Mozambiquan Immigrant Labour in Colonial Malawi 1890s1945." International Journal of African Historical Studies 27, no. 3 (1994): 525-550.

Chirwa, W. C. "Child and Youth Labour on the Nyasaland Plantations, 1890-1953." Journal of Southern African Studies 19, no. 4 (1993): 662-680. 
Chirwa, W. C. "'The Garden of Eden': Sharecropping on the Shire Highlands Estates, 19201945." In White Farms, Black Labour, edited by A. H. Jeeves and J. Crush, 265-280. Oxford: James Currey, 1997.

Conroy, A. C. "The Economics of Smallholder Maize Production in Malawi with Reference to the Market for Hybrid Seed and Fertilizer." Unpublished PhD diss., University of Manchester, 1993.

Davies, W. T. Fifty Years of Progress: An Account of the African Organization of the Imperial Tobacco Company, 1907-1957." Bristol: Imperial Tobacco Company of Great Britain and Ireland, 1958.

Evans, J. Rapid Assessment of the Impact of Policy Changes on Rural Livelihoods in Malawi. Washington, DC: East and Southern Africa Agriculture Division, The World Bank, 1997. Fanon, F. Black Skin, White Masks. New York, NY: Grove, 1968.

Gately, I. La Diva Nicotina: The Story of How Tobacco Seduced the World. London: Simon \& Schuster, 2001.

Goodman, J. Tobacco in History: The Cultures of Dependence. London: Routledge, 1993.

Government of Malawi. Statement of Development Policies 1987-1997. Lilongwe: Office of the President and Cabinet, 1987.

Harrigan, J. From Dictatorship to Democracy: Economic Policy in Malawi, 1964-2000. Aldershot: Ashgate, 2001.

Jaffee, S. Malawi Agriculture: Recent Structural Transformation and Future Prospects Background Paper for The Malawi Growth Prospects Study. Washington, DC: Agriculture Division, The World Bank, 1997.

Jaffee, S. Malawi's Tobacco Sector: Standing on One Strong Leg is Better Than on None. Washington, DC: The World Bank, 2003.

Kandawire, J. A. K. "The Structure of the Colonial System as a Factor in the Underdevelopment of Agriculture in Colonial Nyasaland." Journal of Social Science 4 (1975): $35-45$.

Krishnamurthy, B. S. “Economic Policy: Land and Labour in Nyasaland, 1890-1914.” In The Early History of Malawi, edited by B. Pachai, 384-404. London: Longman, 1972.

Kydd, J. "Malawi in the 1970s - Development Policies and Economic Change." In Malawi: An Alternative Pattern of Development. Conference Proceedings, 296-381. Centre for African Studies, University of Edinburgh, 1984.

Kydd, J., and A. Hewitt. "The Effectiveness of Structural Adjustment Lending: Initial Evidence from Malawi." World Development 14, no. 3 (1986): 347-367.

Kydd, J., and R. E. Christiansen. "Structural Change in Malawi Since Independence: Consequences of a Development Strategy Based on Large-Scale Agriculture." World Development 17, no. 5 (1982): 355-375.

McCracken, J. "Economics and Ethnicity: The Italian Community in Malawi." Journal of African History 32, no. 2 (1991): 313-332.

McCracken, J. "Experts and Expertise in Colonial Malawi." African Affairs 81, no. 322 (1982): 101-116.

McCracken, J. "Peasants, Planters and the Colonial State: The Case of Malawi, 1905-1940." Journal of Eastern African Research and Development 12 (1982): 21-35.

McCracken, J. "Planters, Peasants and the Colonial State: The Impact of the Native Tobacco Board in the Central Province of Malawi." Journal of Southern African Studies 9, no. 2 (1983): 172-192.

McCracken, J. "Sharecropping in Malawi: The Visiting Tenant System in the Central Province, 1920-1968." In Malawi: An Alternative Pattern of Development. Conference Proceedings, 35-65. Centre of African Studies, University of Edinburgh, 1984.

Mintz, S. W. Sweetness and Power: The Place of Sugar in Modern History. New York, NY: Penguin, 1985.

Mkandawire, M. L. C. Poverty, Democracy and Macro Economic Management: The Case of Malawi. Harare: SAPES, 1999.

Moyer-Lee, J., and M. Prowse. How Traceability is Restructuring Malawi's Tobacco Industry. IOB Working Paper No. 2012-05. Antwerp: Institute of Development Policy and Management (IOB), University of Antwerp, 2012.

Mosley, P., and J. Toye. "The Design of Structural Adjustment Programmes." Development Policy Review 6 (1988): 395-414. 
Ng'ong'ola, C. "Malawi's Agricultural Economy and the Evolution of Legislation on the Production and Marketing of Peasant Economic Crops." Journal of Southern African Studies 12, no. 2 (1986): 240-262.

Orr, A. "Green Gold? Burley Tobacco, Smallholder Agriculture, and Poverty Alleviation in Malawi." World Development 28, no. 2 (2000): 347-363.

Oya, C. "Contract Farming in Sub-Saharan Africa: A Survey of Approaches, Debates and Issues." Journal of Agrarian Change 12, no. 1 (2012): 1-33.

Palmer, R. "White Farmers in Malawi: Before and After the Depression." African Affairs 84, no. 335 (1985): 211-245.

Palmer, R. H. "Johnston and Jameson: A Comparative Study in the Imposition of Colonial Rule." In The Early History of Malawi, edited by B. Pachai, 293-322. London: Longman, 1972.

Peters, P. E. "Rural Income and Poverty in a Time of Radical Change in Malawi." Journal of Development Studies 42, no. 2 (2006): 322-345.

Power, J. "Race, Class, Ethnicity, and Anglo-Indian Trade Rivalry in Colonial Malawi." International Journal of African Historical Studies 26, no. 3 (1993): 575-607.

Prowse, M. "Becoming a Bwana and Burley Tobacco in the Central Region of Malawi." Journal of Modern African Studies 47, no. 4 (2009): 575-602.

Prowse, M. "Burley Tobacco, Food Security and Vulnerability: The Changing Nature of Rural Livelihoods in the Central Region of Malawi." Unpublished PhD diss., University of Manchester, 2007.

Prowse, M. A Comparative Value Chain Analysis of Burley Tobacco in Malawi - 2003/04 and 2009/10. IOB Working Paper No. 2011-09. Antwerp: Institute of Development Policy and Management (IOB), University of Antwerp, 2011.

Prowse, M. Contract Farming in Developing Countries - A Review. Paris: Agence Française de Développement, 2012.

Pryor, F. L. The Political Economy of Poverty, Equity and Growth: Malawi and Madagascar. New York, NY: Oxford University Press, 1990.

Pryor, F. L., and C. Chipeta. "Economic Development Through Estate Agriculture: The Case of Malawi." Canadian Journal of African Studies 24, no. 1 (1990): 50-74.

Rangeley, W. H. J. "A Brief History of the Tobacco Industry in Nyasaland: Part 1." Nyasaland Journal 10, no. 1 (1957): 32-51.

Rangeley, W. H. J. "A Brief History of the Tobacco Industry in Nyasaland: Part 2." Nyasaland Journal 10, no. 1 (1957): 62-83.

Sahn, D. E., and J. Arulpragasam. Development Through Dualism?: Land Tenure, Policy, and Poverty in Malawi. Ithaca, NY: Cornell University Press, 1991.

Thomas, S. "Economic Developments in Malawi Since Independence." Journal of Southern African Studies 2, no. 1 (1975): 30-52.

Tobin, R. J., and W. I. Knausenberger. "Dilemmas of Development: Burley Tobacco, the Environment and Economic Growth in Malawi." Journal of Southern African Studies 24, no. 2 (1998): 405-424.

USAID. Agricultural Sector Assistance Program (ASAP), Vol. I: Program Assistance Approval Document. Lilongwe: USAID, 1991.

Vail, L. "The State and the Creation of Colonial Malawi's Agricultural Economy." In Imperialism, Colonialism, and Hunger: East and Central Africa, edited by R. I. Rotberg, 39-87. Lexington, KY: Lexington Books, 1983.

Van Donge, J. K. "Disordering the Market: The Liberalisation of Burley Tobacco in Malawi in the 1990s." Journal of Southern African Studies 28, no. 1 (2002): 89-115.

Vaughan, M. "Food Production and Family Labour in Southern Malawi: The Shire Highlands and Upper Shire Valley in the Early Colonial Period." Journal of African History 23 (1982): 351-364.

Vaughan, M. The Story of an African Famine: Gender and Famine in Twentieth-Century Malawi. Cambridge: Cambridge University Press, 1987.

White, L. Magomero: Portrait of an African Village. Cambridge: Cambridge University Press, 1987.

Wilshaw, C. A Century of Growth: Malawi's Tobacco Industry, 1893-1993. Blantyre: Central Africana, 1994.

Woelk, G., S. Mtisi, and J. P. Vaughan. "Prospects for Tobacco Control in Zimbabwe: A Historical Perspective.” Health Policy 57, no. 3 (2001): 179-192. 
World Bank. Accelerating Malawi's Growth: Long-Term Prospects and Transitional Problems. Washington, DC: Africa Region, The World Bank, 1997.

World Bank. Report and Recommendation of the President of the International Development Association - Malawi. Report No. P-5189-MAI. Washington, DC: The World Bank, 1990. Zeller, M. Growth Linkages of Smallholder Tobacco Production in Malawi. Washington, DC: The World Bank, 1997. 